\title{
Effects of English Language Proficiency on the Choice of Language Learning Strategies by Saudi English-major Undergraduates
}

\author{
Choudhary Z. Javid ${ }^{1}$, Turki S. Al-thubaiti ${ }^{1} \&$ Awwadh Uthman ${ }^{1}$ \\ ${ }^{1}$ Department of Foreign Languages, Taif University, At-Taif, Kingdom of Saudi Arabia \\ Correspondence: Dr. Choudhary Zahid Javid, Assistant Professor, Department of Foreign Languages, Taif \\ University, PO Box 888, At-Taif, Zip Code 21974, Saudi Arabia. Tel: 966-5023-12949. E-mail: \\ chzahidj@hotmail.com
}

Received: October 15, 2012 Accepted: November 22, 2012 Online Published: December 12, 2012

doi:10.5539/elt.v6n1p35 URL: http://dx.doi.org/10.5539/elt.v6n1p35

\begin{abstract}
It is reported that language learning is a creative and dynamic process and the learners are active partners in this process. This trend in language teaching motivated the researchers to investigate the learners' individual differences and the identification of language learning strategies (LLS) has become a major area of interest in this regard because it is suggested that language learners consciously or unconsciously employ different LLS. This research study investigated LLS used by Saudi English-major undergraduates by using SILL version7. Paired Samples t-test was applied to see if significant differences exist as a result of their GPA differences. The informants of this study were 240 English-major undergraduates (low GPA, 106 \& high GPA, 134) enrolled at foreign languages department Taif university. Results reported that the participants with high English language proficiency use language learning strategies more frequently. The participants ranked the metacognitive strategies the highest as compared to other LLS followed by social and cognitive LLS respectively. Among the remaining three categories of LLS, compensation and affective strategies showed mixed preferences but memory strategies were assigned the least mean values by both sample groups. Considering the fact that frequency of LLS usage and English language proficiency are positively linked to each other, it is concluded that it seems necessary to teach language learning strategies explicitly so that even the weaker students should be able to enhance English language proficiency by exploiting a wide range of suitable strategies that are appropriate to different classroom activities and learners' L2 experience.
\end{abstract}

Keywords: language learning strategies, English language proficiency, effect

\section{Introduction}

Though it is common to hear ESL/EFL teachers' complaints regarding the unsatisfactory performance of their students, yet the situation is rather alarming and a lot of research has reported that despite huge government spending, English language teaching in the Arab world in general and Saudi Arabia in particular have not achieved the desire goal of effective ELT (Zughoul, 1986; Sahu, 1999; Rababah, 2003; Al-Jarf, 2008). AlFadly (2003) stated that Arab students remain unable to achieve the desired proficiency in English even after studying the target language for many years. Several studies have been conducted to identifying the causes of Arab students' low proficiency level in the target level (Tushyeh, 1992; Rababah, 2003; Reymond, 2008; Javid, Farooq \& Ajmal, 2012) but there seems a paucity of research to identify the reasons of this low English language proficiency caused by the learner-related factors. A host of studies suggested that efficient language learners, who study English as a second or foreign language, employ a variety of strategies to facilitate their learning $(\mathrm{O}$, Malley, 1987; Cohen, 1998; McDonough, 1995). Oxford \& Nyikos (1989) reported that appropriate language learning strategies (LLS) used by the learners help them achieve higher proficiency in the target language as well as assist them to become self-sufficient learners who possess the abilities such as learner autonomy, self-sufficiency and self-direction: necessary qualities of life-long learners (Nunan, 1988; Corder, 1981). Use of language learning strategies by language learners has been extensively investigated in ESL context but there seems a paucity of LLS research in the EFL context of the Arab world (Radwan, 2010). This scarcity of research is reported in the Arab world in general (El-Dib, 2004; Khalil, 2005; Shmais, 2003; Radwan, 2010) and Saudi Arabia in specific (e.g., Otaibi, 2004). This study is an effort to fill this gap by investigating English-major university undergraduates in a public university of Saudi Arabia. 


\section{Literature Review}

It has been reported that the trend of investigating LLS in learning English as a second/foreign language proliferated during the last three decades when Rubin (1975) enunciated his theory of successful language learners (Jurkovič, 2010). Motallebzadeh \& Mamdoohi (2011, p. 5) stated that successful language learners apply more appropriate and suitable LLS as compared to less successful language learners and said that "...better language learners generally use strategies appropriate to their own stage of learning, personality, age, purpose for learning the language and type of language". Along with several other issues related to learners' ability, personality and skills, the role of LLS in acquiring English as a second language (e.g., Rubin, 1975; Bialystok, 1981; Mansanares \& Russo, 1985; Oxford \& Nyikos, 1989; Ehrman \& Oxford, 1989; Gregerson, 2000: Oxford \& Ehrman, 1995; Wharton, 2000; Griffiths \& Parr, 2001; Hsiao \& Oxford, 2002; Dornyei, 2005) and a foreign language (e.g., Diab, 2000; Abu Shmais, 2003; Al-Otaibi, 2004; Khalil, 2005; Salem, 2006; Riazi, 2007; Eslami \& Al-Buainain, 2009; Radwan, 2010; Al-Buainain, 2010) has been extensively investigated. The significance of LLS is evident from the fact that numerous definitions are found in the literature.

The word 'strategy' is derived from the ancient Greek word 'strategia' meaning the actions or measures taken to win a war (Wikipedia, 2009). Among the earliest definitions, Rigney (1978) identified LLS as a set of actions

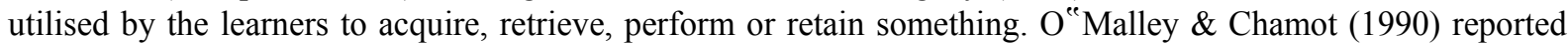
that successful language learners use LLS as tools for active, self-directed involvement to develop the target language communicative ability. Supporting the role of LLS in achieving the much-after goal of self-sufficiency, Holec (1981) reiterated that LLS are instrumental in developing learners' autonomy. LLS have been defined as “...the conscious thoughts and actions that learners take in order to achieve a learning goal" (Chamot, 2004, p. 14) and ".... specific actions taken by the learner to make learning easier, faster, more enjoyable, more self-directed, more effective, more transferable to new situations" (Oxford, 1990, p. 8). The above-mentioned definitions among a multitude of others suggest that LLS are different from other language learning processes and techniques because LLS are based on the learners' recognition of their specific language needs (Wenden \& Rubin, 1987; Eslami, Al-Buainain \& Tzou, 2009). Research has suggested that successful learners develop some sort of meta-awareness of their LLS with the passage of time that help them to critically analyse the language tasks they want to accomplish and choose the most suitable and appropriate LLS to complete the task successfully (Littlejohn, 2008). Much research indicated that language learners consciously or unconsciously employ different LLS (Grenfell \& Harris, 1999; Wharton, 2000). Talking about the main objectives of LLS research, Chamot (2001, pp. 25-26) suggested that:

...two major goals in language learning strategy research are to (1) identify and compare the learning strategies used by more and less successful language learners, and (2) provide instruction to less successful learners that helps them become more successful in their language study.

In an attempt to trace the historical background that initiated LLS-related research, O'Malley \& Chamot, (1995) reported that ELT has witnessed a revolution in the late 60's and early 70's with a shift from the teacher-centered pedagogy to teaching practices that had greater emphasis on learners and learning. The language teachers' learner-centered pedagogy helps the students to become autonomous and independent learners who have the ability to continue their language learning process even in the absence of formal classroom teaching. This pedagogical shift in language teaching developed the learners' active cognitive process with LLS as its most integral component (Littlewood, 1999). This cognitive view of language learning considers that learning is creative process and the learners who actively use appropriate strategies are more successful as compared to the ones who do not do that (Corder, 1981). Khalil (2005) stated that till the end of 1960s, the emphasis of ESL/EFL research has been on investigating teaching methodologies and teaching materials but the focus shifted to the evaluation of the learner-related factors, such as, learners' motivation, attitudes, learning styles, LLS etc. Research has offered valuable insights into the fact that these factors have strong correlation with success in language learning and numerous research studies have tried to identify LLS that successful language learners use to ensure effective learning (See for example, Rubin, 1975; Stern, 1975; Naiman, Frohlich, Stern \& Todesco, 1978; Mansanares \& Russo, 1985; Oxford \& Nyikos, 1989; Dornyei, 1990; Ehrman \& Oxford, 1990; Oxford \& Cohen, 1992; Peng, 2001; Chamot, 2004; Eslami \& Al-Buainain, 2009; Radwan, 2010). The findings of the above-mentioned studies seem to suggest that if appropriate LLS are taught to the less successful language learners, they will be able to take care of their language learning independently and effectively by employing suitable LLS. Several classifications of LLS have been suggested, such as O'Malley \& Chamot's (1990) division of LLS into three main categories: cognitive, metacognitive, and social-affective and Oxford's (1990) classification of LLS into the following six broad categories: memory, cognitive, compensatory, metacognitive, affective, and social. 
Numerous empirical studies have been conducted in different ESL/EFL contexts to investigate the attitudes of successful language learners towards LLS so that these strategies may be taught to the less successful ones to enable them to become more effective language learners (Green and Oxford, 1995; Park, 1997; Grenfell \& Harris, 1999; Wharton, 2000; Griffiths and Parr, 2001). LLS research ranged from simply identifying learners' preferred language strategies (Rubin, 1987; Stern, 1975) to the later trend of identifying the LLS in relation to various language learning variables: English language proficiency, gender, cultural background, motivation etc. (El-Dib, 2004; Hong-Nam \& Leavell, 2006; Khalil, 2005; Magogwe \& Oliver, 2007; Nisbet, Tindel \& Arroyo, 2005; Shmais, 2003). Several studies reported a strong positive link between learners' target language proficiency and the use of appropriate LLS (Shmais, 2003; Khalil, 2005). Various research studies utilised different aspects of language proficiency to investigate their role in applying LLS. These English language proficiency variables included learners' duration of study (Khalil, 2005), learners' self-rating in language proficiency (Oxford \& Nvikos, 1989), learners' scores in TOEFL (Nisbet Tindall \& Arroyo, 2005), learners' GPAs in English language courses (Shmais, 2003), teachers' judgments about their students (Magogwe \& Oliver, 2007) etc. Lan \& Oxford (2003) investigated the EFL context of Taiwanese elementary school learners and found that the students with higher English language proficiency use cognitive, compensatory, affective and metacognitive strategies more effectively as compared to the less proficient learners. Bruen's (2001) study attempted to find out the use of language learning strategies by a group of Irish students who were learning German as a second language and reported a positive correlation of German proficiency with the use of strategies.

\section{Research Objectives/Questions}

This study is directed by the following research questions:

a. What are the most frequent language learning strategies used by Saudi English-major students enrolled at Foreign Language Department, Taif University?

b. Are there any statistically significant differences as a result of their GPA differences?

c. What strategies are correlated with learners' high GPA?

\section{Research Methodology}

\subsection{Participants}

English-major university undergraduates studying at the Foreign Languages Department, Taif University (FLDTU) were the participants of this empirical study. These students join Taif University after completing 12 years of formal education at different schools and study English as a compulsory subject since their $6^{\text {th }}$ grade. After joining FLDTU, they are taught English language courses related to different sub-disciplines, i.e., four language skills, grammar, linguistics, literature and translation.

\subsection{Instrumentation}

To generate the data concerning the responses of the participants of the study regarding their LLS use, Strategy Inventory for Language Learning (SILL: version 7.0) questionnaire designed by (Oxford, 1990) was administered to English-major university undergraduates studying at FLDTU. SILL is an instrument that has been widely used world-wide to record the frequency of LLS employed by the learners. This questionnaire has 50 items included in 6 subcategories of LLS as shown in the following table:

Table 1. LLS items distribution according to 6 types

\begin{tabular}{llll}
\hline No & LLS strategy & Items & Total \\
\hline 1 & Memory & $1-9$ & 9 \\
\hline 2 & Cognitive & $10-23$ & 14 \\
\hline 3 & Compensation & $24-29$ & 6 \\
\hline 4 & Metacognitive & $30-38$ & 9 \\
\hline 5 & Affective & $39-44$ & 6 \\
\hline 6 & Social & $45-50$ & 6 \\
\hline
\end{tabular}

Cronbach alpha coefficient for internal consistency for SILL (Oxford, 1990/Version 7) questionnaire was 0.86. Oxford (1996, p. 29) stated that reliability "is determined with the whole instrument because the six categories are strongly correlated with the SILL mean $(0.66-0.81)$ and moderately correlated with each other $(0.35-0.61)$ ". 
The Arabic version of the questionnaire was administered to the English-major male and female students (freshmen, sophomores, juniors and seniors). The researchers distributed 35 questionnaires to each of the eight groups mentioned above. Incomplete questionnaires, questionnaires with no GPA mentioned, or questionnaire with same responses (i.e., all strongly agree --- strongly disagree are ticked) were rejected. The remaining 240 questionnaire were divided into two groups: participants with high GPA and the ones with low GPA. One hundred and six questionnaires were identified as the ones filled in by the participants with low GPA and 134 questionnaires were with high GPA.

\subsection{Data Analysis}

Arabic Translation of SILL questionnaire (See Appendix \# 2) was administered to all English-major university undergraduates studying at FLDTU during the second semester of the academic year 2011/2012. The responses of the participants were manually coded and analysed by using SPSS version 10. The descriptive statistics i.e., the means, medians, standard deviations and percentages of the samples' responses regarding the frequency of LLS used by Saudi English-major university undergraduates were calculated. Independent Samples T-Test was applied to identify any statistically significant differences as a result of the students' GPA differences.

\section{Results}

The results of Independent-Samples T-test are presented in the tables below. For the purpose of the description of the results, the following criteria were followed: mean value of 3.6 or above is considered high ranking, 2.99 or below is considered low ranking where as the values between these two (i.e., $3-3.59$ ) are considered medium ranking.

Table 2. Results of LLS strategies (Memory)

\begin{tabular}{|c|c|c|c|c|c|c|c|c|}
\hline The questionnaire items & Group & $\mathrm{n}$ & $\mathrm{M}$ & SD & $\mathrm{T}$ & Df & $\mathrm{p}$ value & \\
\hline \multirow[t]{2}{*}{1 Item 1} & Low GPA & 106 & 3.3962 & 1.0390 & -1.083 & 238 & .280 & $\mathrm{p}>0.05$ \\
\hline & High GPA & 134 & 3.5522 & 1.1605 & -1.097 & 234.33 & .274 & \\
\hline \multirow[t]{2}{*}{2 Item 2} & Low GPA & 106 & 2.8113 & 1.1137 & -2.054 & 237 & .041 & $\mathrm{p}<0.05$ \\
\hline & High GPA & 133 & 3.5789 & 3.7157 & -2.259 & 160.86 & .025 & \\
\hline \multirow[t]{2}{*}{$3 \quad$ Item 3} & Low GPA & 106 & 3.5472 & 1.0248 & .318 & 238 & .751 & $\mathrm{p}>0.05$ \\
\hline & High GPA & 134 & 3.5000 & 1.2247 & .325 & 237.22 & .746 & \\
\hline \multirow[t]{2}{*}{$4 \quad$ Item 4} & Low GPA & 106 & 2.9245 & 1.3501 & -.951 & 238 & .343 & $\mathrm{p}>0.05$ \\
\hline & High GPA & 134 & 3.0896 & 1.3234 & -.949 & 223.38 & .344 & \\
\hline \multirow[t]{2}{*}{ Item 5} & Low GPA & 106 & 2.1509 & 1.1856 & -.088 & 238 & .930 & $\mathrm{p}>0.05$ \\
\hline & High GPA & 134 & 2.1642 & 1.1252 & -.088 & 219.83 & .930 & \\
\hline \multirow[t]{2}{*}{$6 \quad$ Item 6} & Low GPA & 106 & 2.0566 & 1.1283 & -.118 & 238 & .906 & $\mathrm{p}>0.05$ \\
\hline & High GPA & 134 & 2.0746 & 1.2054 & -.119 & 231.32 & .905 & \\
\hline \multirow[t]{2}{*}{$7 \quad$ Item 7} & Low GPA & 106 & 2.7453 & 1.1132 & -1.402 & 238 & .162 & $p>0.05$ \\
\hline & High GPA & 134 & 2.9552 & 1.1817 & -1.412 & 230.82 & .159 & \\
\hline \multirow[t]{2}{*}{$8 \quad$ Item 8} & Low GPA & 106 & 2.9906 & .9309 & .041 & 238 & .968 & $\mathrm{p}>0.05$ \\
\hline & High GPA & 134 & 2.9851 & 1.1171 & .042 & 237.33 & .967 & \\
\hline \multirow[t]{2}{*}{9 Item 9} & Low GPA & 106 & 3.5755 & 1.2417 & .288 & 238 & .774 & $\mathrm{p}>0.05$ \\
\hline & High GPA & 134 & 3.5299 & 1.1996 & .287 & 221.81 & .774 & \\
\hline
\end{tabular}

Results of the items meant to elicit participants' LLS strategies related to memory have been described in the table above. The participants with high GPA assigned higher mean values to the majority of the items except the $3^{\text {rd }}$ and $8^{\text {th }}$ questionnaire items that indicated that comparatively higher mean values were allocated by the participants with low GPA for these two items. Another interesting result is that no item has been assigned high ranking whereas four items $(5,6,7 \& 8)$ were assigned low mean values by both groups. Items 2 and 4 reported low mean by the low GPA group. All the other items fell in the medium category because of the medium ranking values. The data analysis indicated that there did not exist any significant differences in the responses of both the groups except for the item 2 as reported by Independent-Samples T-test results: high GPA group's value was 3.57 as compared to low GPA group's mean value of only 2.81 indicating that these students don't use their 
audio-visual capacities to memorise and retain English lexical items.

Table 2 presents the results generated through the data analysis of the items that elicited participants' responses related to their cognitive LLS strategies usage.

Table 3. Results of LLS strategies (cognitive)

\begin{tabular}{|c|c|c|c|c|c|c|c|c|c|}
\hline \multicolumn{2}{|c|}{ The questionnaire items } & \multirow{2}{*}{$\begin{array}{l}\text { Group } \\
\text { Low GPA }\end{array}$} & \multirow{2}{*}{$\begin{array}{l}\mathrm{n} \\
106\end{array}$} & \multirow{2}{*}{$\begin{array}{l}\mathrm{M} \\
3.5283\end{array}$} & \multirow{2}{*}{$\begin{array}{l}\text { SD } \\
1.2127\end{array}$} & \multirow{2}{*}{$\begin{array}{l}\mathrm{T} \\
-.109\end{array}$} & \multirow{2}{*}{$\begin{array}{l}\mathrm{df} \\
238\end{array}$} & \multicolumn{2}{|c|}{$\mathrm{p}$ value } \\
\hline 10 & Item 10 & & & & & & & .913 & $\mathrm{p}>0.05$ \\
\hline & & High GPA & 134 & 3.5448 & 1.1213 & -.108 & 216.77 & .914 & \\
\hline \multirow[t]{2}{*}{11} & Item 11 & Low GPA & 106 & 3.5566 & 1.3528 & -2.515 & 238 & .013 & $\mathrm{p}<0.05$ \\
\hline & & High GPA & 134 & 3.9478 & 1.0571 & -2.444 & 195.01 & .015 & \\
\hline \multirow[t]{2}{*}{12} & Item 12 & Low GPA & 106 & 3.2170 & 1.1711 & -2.164 & 238 & .031 & $\mathrm{p}<0.05$ \\
\hline & & High GPA & 134 & 3.5448 & 1.1609 & -2.162 & 224.55 & .032 & \\
\hline \multirow[t]{2}{*}{13} & Item 13 & Low GPA & 106 & 3.3585 & 1.0884 & -.873 & 238 & .383 & $\mathrm{p}>0.05$ \\
\hline & & High GPA & 134 & 3.4851 & 1.1355 & -.878 & 229.39 & .381 & \\
\hline \multirow[t]{2}{*}{14} & Item 14 & Low GPA & 106 & 3.1604 & 1.2121 & -1.777 & 238 & .077 & $\mathrm{p}>0.05$ \\
\hline & & High GPA & 134 & 3.4328 & 1.1533 & -1.767 & 220.11 & .079 & \\
\hline \multirow[t]{2}{*}{15} & Item 15 & Low GPA & 106 & 3.5849 & 1.3998 & -1.008 & 237 & .314 & $\mathrm{p}>0.05$ \\
\hline & & High GPA & 133 & 3.7669 & 1.3756 & -1.006 & 223.51 & .315 & \\
\hline \multirow[t]{2}{*}{16} & Item 16 & Low GPA & 106 & 3.2075 & 1.2009 & -.740 & 238 & .460 & $\mathrm{p}>0.05$ \\
\hline & & High GPA & 134 & 3.3284 & 1.2965 & -.747 & 232.10 & .456 & \\
\hline \multirow[t]{2}{*}{17} & Item 17 & Low GPA & 106 & 2.7453 & 1.3170 & -3.350 & 238 & .001 & $\mathrm{p}<0.05$ \\
\hline & & High GPA & 134 & 3.2910 & 1.2004 & -3.314 & 215.03 & .001 & \\
\hline \multirow[t]{2}{*}{18} & Item 18 & Low GPA & 106 & 3.2642 & 1.2895 & -2.208 & 238 & .028 & $\mathrm{p}<0.05$ \\
\hline & & High GPA & 134 & 3.6269 & 1.2426 & -2.199 & 221.53 & .029 & \\
\hline \multirow[t]{2}{*}{19} & Item 19 & Low GPA & 106 & 3.2642 & 1.1322 & .265 & 238 & .791 & $\mathrm{p}>0.05$ \\
\hline & & High GPA & 134 & 3.2239 & 1.1993 & .267 & 230.65 & .790 & \\
\hline \multirow[t]{2}{*}{20} & Item 20 & Low GPA & 106 & 2.8396 & 1.0613 & -.565 & 238 & .573 & $\mathrm{p}>0.05$ \\
\hline & & High GPA & 134 & 2.9179 & 1.0694 & -.566 & 226.19 & .572 & \\
\hline \multirow[t]{2}{*}{21} & Item 21 & Low GPA & 105 & 3.4857 & 1.1612 & -.657 & 237 & .512 & $\mathrm{p}>0.05$ \\
\hline & & High GPA & 134 & 3.5896 & 1.2518 & -.663 & 230.31 & .508 & \\
\hline \multirow[t]{2}{*}{22} & Item 22 & Low GPA & 106 & 2.9151 & 1.1962 & -1.647 & 238 & .101 & $\mathrm{p}>0.05$ \\
\hline & & High GPA & 134 & 3.1791 & 1.2616 & -1.657 & 230.30 & .099 & \\
\hline \multirow[t]{2}{*}{23} & Item 23 & Low GPA & 106 & 3.2264 & 1.2366 & -1.008 & 238 & .315 & $\mathrm{p}>0.05$ \\
\hline & & High GPA & 134 & 3.3881 & 1.2318 & -1.007 & 225.06 & .315 & \\
\hline
\end{tabular}

This is the biggest component of this questionnaire with a total number of items reaching 14. Results clearly indicate that the majority of the items were assigned mean values of medium range by both the sample groups. There are only three items $(11,15, \& 18)$ of this questionnaire category that have been allotted high values and that was only by the sample group with high GPA whereas the values allocated by low GPA group fell in the category of medium range for these items. "I try to find patterns in English" is the only item that has been assigned low mean value by both the groups and items 15 and 22 were the others which were dealt with similarly by low GPA group. All the other questionnaire items followed the trend that has been exhibited in the previous category that overall higher values were assigned by high GPA group except item 19 that reported opposite trend suggesting that weaker students with low GPA depend on the mother tongue alternative for new English words they want to learn. Results indicate that four items $(11,12,17 \& 18)$ exhibited statistically significant difference $(p<0.05)$ in the responses of the sample groups in favour of high GPA participants who gave out higher mean values in this regard. 
Table 3. Results of LLS strategies (compensation)

\begin{tabular}{|c|c|c|c|c|c|c|c|c|c|}
\hline \multicolumn{2}{|c|}{ The questionnaire items } & \multirow{2}{*}{$\begin{array}{l}\text { Group } \\
\text { Low GPA }\end{array}$} & \multirow{2}{*}{$\begin{array}{l}\mathrm{N} \\
106\end{array}$} & \multirow{2}{*}{$\begin{array}{l}\text { M } \\
3.4245\end{array}$} & \multirow{2}{*}{$\begin{array}{l}\text { SD } \\
1.1788\end{array}$} & \multirow{2}{*}{$\begin{array}{l}\mathrm{T} \\
-2.337\end{array}$} & \multirow{2}{*}{$\frac{\mathrm{df}}{238}$} & \multicolumn{2}{|c|}{$\mathrm{p}$ value } \\
\hline 24 & Item 24 & & & & & & & .020 & $\mathrm{p}<0.05$ \\
\hline & & High GPA & 134 & 3.7612 & 1.0490 & -2.306 & 212.064 & .022 & \\
\hline \multirow[t]{2}{*}{25} & Item 25 & Low GPA & 106 & 3.2358 & 1.1592 & -1.142 & 238 & .254 & $\mathrm{p}>0.05$ \\
\hline & & High GPA & 134 & 3.4179 & 1.2761 & -1.155 & 233.442 & .249 & \\
\hline \multirow[t]{2}{*}{26} & Item 26 & Low GPA & 106 & 2.9057 & 1.3699 & -.316 & 238 & .753 & $\mathrm{p}>0.05$ \\
\hline & & High GPA & 134 & 2.9627 & 1.4057 & -.317 & 227.923 & .752 & \\
\hline \multirow[t]{2}{*}{27} & Item 27 & Low GPA & 106 & 2.5189 & 1.1232 & -.376 & 238 & .707 & $\mathrm{p}>0.05$ \\
\hline & & High GPA & 134 & 2.5746 & 1.1528 & -.377 & 227.946 & .706 & \\
\hline \multirow[t]{2}{*}{28} & Item 28 & Low GPA & 106 & 3.5849 & 1.1700 & .117 & 238 & .907 & $\mathrm{p}>0.05$ \\
\hline & & High GPA & 134 & 3.5672 & 1.1662 & .117 & 225.124 & .907 & \\
\hline \multirow[t]{2}{*}{29} & Item 29 & Low GPA & 106 & 3.6981 & 1.2202 & -1.485 & 238 & .139 & $\mathrm{p}>0.05$ \\
\hline & & High GPA & 134 & 3.9179 & 1.0694 & -1.463 & 210.115 & .145 & \\
\hline
\end{tabular}

Table 3 details the data analysis of the compensation LLS strategies and the participants report medium to high ranking for the majority of the items except items 26 and 27 with low mean values of less than 3(low GPA, 2.90: high GPA, 2.96 \& low GPA, 2.51: high GPA, 2.57 respectively). The results suggest that Saudi English-major undergraduates do not try to make up new words and do not prefer to read English without looking up new words. This habit seems the main reason behind slow reading speed of the students supporting the findings of Javid \& Khairi (2011) who reported that Saudi undergraduates suffer from severe handicap in reading skills. Both sample groups reported strong liking for item 29 by assigning high ranking to it. Item 24 was also assigned higher value by high GPA group indicating that they try to guess the meaning of the unknown words they encounter in their readings. Significant difference has been reported for this item that informs that low GPA group does not use this reading technique. There is only one item in which low GPA group assigned higher mean value as compared to the other group.

Table 4. Results of LLS strategies (Metacognitive)

\begin{tabular}{|c|c|c|c|c|c|c|c|c|c|}
\hline \multicolumn{2}{|c|}{ The questionnaire items } & \multirow{2}{*}{$\begin{array}{l}\text { Group } \\
\text { Low GPA }\end{array}$} & \multirow{2}{*}{$\begin{array}{l}\mathrm{n} \\
106\end{array}$} & \multirow{2}{*}{$\begin{array}{l}M \\
3.4434\end{array}$} & \multirow{2}{*}{$\begin{array}{l}\text { SD } \\
1.1959\end{array}$} & \multirow{2}{*}{$\begin{array}{l}\mathrm{T} \\
-2.140\end{array}$} & \multirow{2}{*}{$\begin{array}{l}\mathrm{df} \\
238\end{array}$} & \multicolumn{2}{|c|}{$\mathrm{p}$ value } \\
\hline 30 & Item 30 & & & & & & & .033 & $\mathrm{p}<0.05$ \\
\hline & & High GPA & 134 & 3.7612 & 1.0980 & -2.119 & 215.932 & .035 & \\
\hline \multirow[t]{2}{*}{31} & Item 31 & Low GPA & 106 & 3.4906 & 1.2051 & -.874 & 238 & .383 & $\mathrm{p}>0.05$ \\
\hline & & High GPA & 134 & 3.6194 & 1.0746 & -.862 & 212.317 & .389 & \\
\hline \multirow[t]{2}{*}{32} & Item 32 & Low GPA & 106 & 3.9811 & 1.1211 & -1.302 & 238 & .194 & $\mathrm{p}>0.05$ \\
\hline & & High GPA & 134 & 4.1642 & 1.0491 & -1.292 & 218.201 & .198 & \\
\hline \multirow[t]{2}{*}{33} & Item 33 & Low GPA & 106 & 3.9906 & 1.1670 & -.878 & 238 & .381 & $\mathrm{p}>0.05$ \\
\hline & & High GPA & 134 & 4.1194 & 1.0971 & -.872 & 218.739 & .384 & \\
\hline \multirow[t]{2}{*}{34} & Item 34 & Low GPA & 106 & 3.0943 & 1.2538 & -1.207 & 238 & .229 & $\mathrm{p}>0.05$ \\
\hline & & High GPA & 134 & 3.2836 & 1.1673 & -1.197 & 217.594 & .233 & \\
\hline \multirow[t]{2}{*}{35} & Item 35 & Low GPA & 106 & 3.3208 & 1.2386 & -2.365 & 238 & .019 & $\mathrm{p}<0.05$ \\
\hline & & High GPA & 134 & 3.7015 & 1.2387 & -2.365 & 225.450 & .019 & \\
\hline \multirow[t]{2}{*}{36} & Item 36 & Low GPA & 106 & 3.3679 & 1.1656 & -1.177 & 238 & .240 & $\mathrm{p}>0.05$ \\
\hline & & High GPA & 134 & 3.5448 & 1.1478 & -1.175 & 223.877 & .241 & \\
\hline \multirow[t]{2}{*}{37} & Item 37 & Low GPA & 106 & 3.1132 & 1.2292 & -1.924 & 238 & .056 & $\mathrm{p}>0.05$ \\
\hline & & High GPA & 134 & 3.4179 & 1.2096 & -1.920 & 223.803 & .056 & \\
\hline & Item 38 & Low GPA & 106 & 3.8774 & 1.1929 & -1.964 & 238 & .051 & $\mathrm{p}>0.05$ \\
\hline & & High GPA & 134 & 4.1567 & 1.0101 & -1.926 & 205.665 & .055 & \\
\hline
\end{tabular}


Participants' responses for metacognitive LLS strategies have been elicited by the nine items mentioned in table 4 and the results revealed that the participants showed strong liking for this strategies. Six items of this category have been assigned high mean values either by both the groups or at least by the high GPA sample group. Highest mean values of more than 4 have been allocated to items 32,33 and 38 (4.16, 4.11, \& 4.15 respectively). No item of this category reported low preference by either of the group. Significant difference was reported for the items which elicited participants' responses towards finding out the ways and opportunities to practice English and look for people they can talk to in English showing their strong desire to be proficient in English language.

Table 5. Results of LLS strategies (Affective)

\begin{tabular}{|c|c|c|c|c|c|c|c|c|c|}
\hline \multicolumn{2}{|c|}{ The questionnaire items } & \multirow{2}{*}{$\begin{array}{l}\text { Group } \\
\text { Low GPA }\end{array}$} & \multirow{2}{*}{$\begin{array}{l}\mathrm{N} \\
106\end{array}$} & \multirow{2}{*}{$\begin{array}{l}\mathrm{M} \\
3.3302\end{array}$} & \multirow{2}{*}{$\begin{array}{l}\text { SD } \\
1.2089\end{array}$} & \multirow{2}{*}{$\begin{array}{l}\mathrm{T} \\
.606\end{array}$} & \multirow{2}{*}{$\begin{array}{l}\mathrm{df} \\
238\end{array}$} & \multicolumn{2}{|c|}{$\mathrm{p}$ value } \\
\hline 39 & Item 39 & & & & & & & .545 & $\mathrm{p}>0.05$ \\
\hline & & High GPA & 134 & 3.2313 & 1.2915 & .610 & 231.32 & .542 & \\
\hline \multirow[t]{2}{*}{40} & Item 40 & Low GPA & 106 & 3.4340 & 1.1631 & -2.972 & 238 & .003 & $\mathrm{p}<0.05$ \\
\hline & & High GPA & 134 & 3.8806 & 1.1506 & -2.968 & 224.35 & .003 & \\
\hline \multirow[t]{2}{*}{41} & Item 41 & Low GPA & 106 & 3.3208 & 1.2539 & -.132 & 238 & .895 & $\mathrm{p}>0.05$ \\
\hline & & High GPA & 134 & 3.3433 & 1.3495 & -.134 & 231.87 & .894 & \\
\hline \multirow[t]{2}{*}{42} & Item 42 & Low GPA & 106 & 3.1226 & 1.3071 & -1.071 & 238 & .285 & $\mathrm{p}>0.05$ \\
\hline & & High GPA & 134 & 3.2985 & 1.2265 & -1.064 & 218.50 & .289 & \\
\hline \multirow[t]{2}{*}{43} & Item 43 & Low GPA & 106 & 2.2170 & 1.2649 & -.852 & 238 & .395 & $\mathrm{p}>0.05$ \\
\hline & & High GPA & 134 & 2.3657 & 1.4011 & -.862 & 233.82 & .389 & \\
\hline \multirow[t]{2}{*}{44} & Item 44 & Low GPA & 106 & 3.2453 & 1.3224 & .300 & 238 & .764 & $\mathrm{p}>0.05$ \\
\hline & & High GPA & 134 & 3.1940 & 1.3063 & .300 & 224.19 & .765 & \\
\hline
\end{tabular}

The results of affective LLS strategies have also been found in line with metacognitive strategies because all the items except the second last one have been allotted low ranking. Two items (39 \& 44) exhibited different trend and the values assigned by the low GPA group were higher than the ones ranked by the high GPA group. "I encourage myself to speak English even when I am afraid of making mistakes" is the only item which showed significant difference in the responses of the groups strongly indicating that inhibition is a significant factor that provides a strong handicap to achieve proficiency in the target language.

Table 6. Results of LLS strategies (Social)

\begin{tabular}{|c|c|c|c|c|c|c|c|c|c|}
\hline \multicolumn{2}{|c|}{ The questionnaire items } & \multirow{2}{*}{$\begin{array}{l}\text { Group } \\
\text { Low GPA }\end{array}$} & \multirow{2}{*}{$\frac{N}{106}$} & \multirow{2}{*}{$\begin{array}{l}M \\
3.5660\end{array}$} & \multirow{2}{*}{$\begin{array}{l}\text { SD } \\
1.2575\end{array}$} & \multirow{2}{*}{$\begin{array}{l}\mathrm{T} \\
-.336\end{array}$} & \multirow{2}{*}{$\frac{\mathrm{df}}{238}$} & \multicolumn{2}{|c|}{$p$ value } \\
\hline 45 & Item 45 & & & & & & & .737 & $\mathrm{p}>0.05$ \\
\hline & & High GPA & 134 & 3.6194 & 1.1939 & -.334 & 219.874 & .739 & \\
\hline \multirow[t]{2}{*}{46} & Item 46 & Low GPA & 106 & 3.2925 & 1.4407 & -2.153 & 238 & .032 & $\mathrm{p}<0.05$ \\
\hline & & High GPA & 134 & 3.6642 & 1.2321 & -2.114 & 206.951 & .036 & \\
\hline \multirow[t]{2}{*}{47} & Item 47 & Low GPA & 106 & 2.7547 & 1.2559 & -2.369 & 238 & .019 & $\mathrm{p}<0.05$ \\
\hline & & High GPA & 134 & 3.1493 & 1.3007 & -2.379 & 228.756 & .018 & \\
\hline \multirow[t]{2}{*}{48} & Item 48 & Low GPA & 106 & 3.3019 & 1.2886 & -2.129 & 238 & .034 & $\mathrm{p}<0.05$ \\
\hline & & High GPA & 134 & 3.6493 & 1.2279 & -2.117 & 220.286 & .035 & \\
\hline \multirow[t]{2}{*}{49} & Item 49 & Low GPA & 106 & 3.4151 & 1.2863 & -1.542 & 238 & .124 & $\mathrm{p}>0.05$ \\
\hline & & High GPA & 134 & 3.6642 & 1.2074 & -1.530 & 218.552 & .127 & \\
\hline \multirow[t]{2}{*}{50} & Item 50 & Low GPA & 106 & 3.4340 & 1.3453 & -2.996 & 238 & .003 & $\mathrm{p}<0.05$ \\
\hline & & High GPA & 134 & 3.9328 & 1.2275 & -2.965 & 215.164 & .003 & \\
\hline
\end{tabular}

The same trend of high preference as noticed in the previous two tables is quite evident in the results of social LLS strategies and high GPA group assigned high mean values to all the items of this category except item 47 (low GPA: 2.75 \& high GPA: 3.14). This item reveals the psychological underpinnings of Saudi students that 
they do not prefer to use target language with their class fellows supporting the findings of Javid (2011) who reported that Saudi medical undergraduate do not like to let their weaknesses known to their peers. Independent Samples T-test results revealed significant differences in four items of this category (46, 47, 48 \& 50) strongly suggesting that those students who overcome their social inhibitions and let the others correct their mistakes perform better and achieve English language proficiency quickly as compared to their shy counterparts in this regard.

\section{Discussion and Conclusions}

The descriptive analysis of the various LLS categories has revealed that the participants of this study who have high GPA assigned higher values to nearly all the 50 SILL items except few exceptions (memory, 3 \& 8; cognitive, 9; compensation, 28; metacognitive, none; affective, $39 \& 44$; social, none) where low GPA group allocated higher values for these items as compared to the ones assigned by high GPA group but interesting fact is that no item has shown significant difference in their response. This result is in accord with the findings of the previous research conducted in the various countries and quite consistently reported a positive link between the use of language learning strategies and their proficiency in English (Magogwe \& Oliver, 2007; Khalil, 2005; Shmais, 2003; Lan \& Oxford, 2003; Park, 1997). The study conducted by Radwan (2010) also revealed that more proficient Omani students use language learning strategies more frequently as compared to the less proficient ones. Although majority of the studies support the positive connection between LLS frequency and the target language proficiency, yet certain contradictory findings have also been reported. Shamais (2003) stated that high GPA students' frequency of LLS use was limited to only metacognitive strategies as compared to the low GPA students. The same trend has been reported by Nisbet, Tindel \& Arroyo (2005) who found out a difference of only $4 \%$ variation in TOEFL scores and frequency of LLS use in only one category, i.e., metacognitive LLS. The results offer significant insights into the fact that it is the awareness of the language needs that force and motivate the more proficient students to use LLS that are instrumental in acquiring the target language through analysing, planning, practicing, reasoning and evaluating their learning. It has also been suggested that "these learners exercise a great deal of control over their emotions and attitudes through lowering their anxiety levels and increasing their motivation levels" (Radwan, 2010, p. 140).

Saudi English-major undergraduates represented by the participants of this study ranked the metacognitive strategies the highest as compared to other LLS strategies followed by social and cognitive LLS strategies respectively. The finding is in line with Radwan (2010) who reported that Omani students favoured metacognitive LLS strategies to all other components of SILL inventory. The same has been revealed by Al-Buainain (2010) and Riazi (2007) who stated that the participants of their studies showed their preference for metacognitive strategies followed by cognitive strategies. The preference of metacognitive strategies has also been reported in several other studies conducted in the various parts of the world (Hong-Nam \& Leavell, 2006; Magogwe \& Oliver, 2007; Nisbet, Tindall \& Arroyo, 2005). Another interesting finding is that the participants with high GPA assigned highest mean value of more than 4.0 to 3 metacognitive strategies (I pay attention when someone is speaking English, 4.16; I think about my progress in learning English, 4.15; I try to find out how to be a better learner of English, 4.11) whereas no other item of any other category has been assigned the highest value of 4.0 or above. Furthermore, this is the only LLS category in which no item was assigned low value by either of the groups. The results of independent-samples t-test revealed that there wad only one item which was allocated low mean value (I practice English with other students: low GPA, 2.75 \& high GPA, 3.14) and all the other items were allotted high ranking by the high GPA group and medium ranking by low GPA group. Out of the total 6 items in this category, 4 items were reported to have significant difference in the perception of the groups. As far the cognitive strategies are concerned, there was only one item which was assigned low value by both groups (I try to find patterns in English: low GPA, 2.83 \& high GPA, 2.91) and two items that reported low ranking by low GPA group (I write notes, messages, letters, or reports in English: low GPA, 2.74 \& high GPA, 3.29 - I try not to translate word-for-word: low GPA, $2.91 \&$ high GPA, 3.17). This finding seems to suggest that low proficiency students try to avoid writing skills and have higher tendency of word for word translation using their mother tongue. All other items of this category were assigned either high or medium values by both the groups.

Among the remaining three categories of LLS strategies, compensation and affective strategies showed mixed preferences but memory LLS strategies were assigned the least mean values by both sample groups confirming the findings of research conducted in the Arab world (Al-Buainain, 2010; Radwan, 2010; Khalil, 2005; Al-Otaibi, 2004 etc.) and elsewhere (Hong- Nam \& Leavell, 2006: Rong, 1999; Goh \& Foong, 1997 etc.). This result supported the findings of (Al-Buainain, 2010) who reported that the least favoured LLS strategies as perceived by the participants of his study remained memory strategies and affective strategies respectively. Assigning 
memory LLS strategies the least mean values seems quite interesting rather surprising finding considering the fact that Arabs are reported to have a strong memory. In addition to that, it has also been reported that educational system in most of the Arab countries requires the students to rely on rote memorisation. Radwan (2010, p. 138) has offered a probable reason behind this apparently surprising finding by stating that it may be due to 'students' displeasure with the conservative educational methods and techniques....the students' recognition that excelling in learning a foreign language requires actively involving themselves in the learning process, seeking opportunities to use the language, cooperating with their peers, etc".

As reported by much research, the participants with high GPA have overall positive attitude towards LLS as indicated by their assigned higher ranking to the vast majority of SILL inventory as compared to their low GPA counterparts offering valuable insights that frequency of LLS usage and English language proficiency are positively linked to each other. Considering this finding, it is concluded that it seems necessary to teach language learning strategies explicitly so that even the weaker students should be able to enhance English language proficiency by exploiting a wide range of suitable strategies "appropriate to different instructional task and activities that constitute an essential part of the classroom L2 experience" (Khalil, 2005, p. 115). Furthermore, it can be inferred that it is rather important for weaker students that the teachers should teach them explicit strategy usage as it is emphasised that "explicitly describing, discussing, and reinforcing strategies in the classroom can have a direct payoff on student outcomes" (Cohen, Weaver \& Li, 1995, p. 29).

This empirical study investigated Saudi English-major university undergraduates' LLS usage in respect to one important variable, i.e., participants' English proficiency judged by their GPA. There seems an urgent need to investigate the effect of other relevant variables such as gender, number of years of study, university major, motivational orientations etc. on LLS use to enrich this important area that has significant pedagogical implications for EFL teaching/learning.

\section{References}

Abu Shmais, W. (2003). Language Learning Strategy use in Palestine. TESL-EJ, 7(2), 1-17.

Al-Buainain, H. (2010). Language Learning Strategies Employed by English Majors at Qatar University: Questions and Queries. Asiatic, 4(2), 92-120.

Al-Otaibi, G. N. (2004). Language Learning Strategy Use among Saudi EFL Students and its Relationship to Language Proficiency Level, Gender and Motivation. Doctoral Dissertation. Indiana University of Pennsylvania, Indiana, PA.

AlFadly, H. O. (2003). The English Language Teaching Situation in Yemen: A Case Study. Bulletin of Higher Education Research, 2, Malaysia.

Al-Jarf, R. (2008). The Impact of English as an International Language (EIL) upon Arabic in Saudi Arabia. Asian EFL Journal, 10(4), 193-210.

Al-Otaibi, G. (2004). Language learning use among Saudi EFL students and its relationship to language proficiency level, gender and motivation. Doctoral Dissertation: Indiana University of Pennsylvania, Indiana, PA.

Bruen, J. (2001). Strategies for success: Profiling the effective learner of German. Foreign Language Annals, 34(3), 216-225. http://dx.doi.org/10.1111/j.1944-9720.2001.tb02403.x

Bialystok, E. (1981). The Role of Conscious Strategies in Second Language Proficiency. Modern Language Journal, 65(1), 24-35.

Chamot, A. (2004). Issues in language learning strategy research and teaching. Electronic Journal of Foreign Language Teaching, 1(1), 14-26.

Chamot, A. (2001). The role of learning strategies in second language acquisition. In M P Breen (Ed.), Learner contributions to language learning: New directions in research (pp. 25-43). Harlow, England: Longman.

Chamot, A. U., \& O'Malley, J. M. (1996). Implementing the cognitive academic language learning approach (CALLA). In R L Oxford (Ed.), Language learning strategies around the world: Cross-cultural perspectives (pp. 167-173). Honolulu: University of Hawaii at Manoa.

Cohen, A. D. (1998). Strategies in learning and using a second language. London, UK: Longman.

Cohen, A. D., Weaver, S., \& Li, T. Y. (1998). The impact of strategies-based instruction on speaking a foreign language. In A Cohen (Ed), Strategies in learning and using a second language (pp. 107-156). London: Longman. 
Corder, S. P. (1981). Error Analysis and Interlanguage. Oxford, UK: Oxford UP.

Diab, R. L. (2000). Political and Socio-cultural Factors in Foreign Language Education: The Case of Lebanon. Texas Papers in Foreign Language Education, 5(1), 177-87.

Dornyei, Z. (1990). Conceptualizing motivation in foreign language learning. Language Learning, 40, 45-79. http://dx.doi.org/10.1111/j.1467-1770.1990.tb00954.x

Dörnyei, Z. (2005). The psychology of the language learner. Mahwah, NJ: Erlbaum.

Ehrman, M., \& Oxford, R. (1989). Effects of sex differences, career choice, and psychological type on adult language learning strategies. The Modern Language Journal, 73, 1-12.

Ehrman, M. E., \& Oxford, R. L. (1990). Adult learning styles and strategies in an intensive training setting. The Modern Language Journal, 74, 311-26.

El-Dib, M. (2004). Language learning strategies in Kuwait: Links to gender, language level, and culture in a hybrid context. Foreign Language Annals, 37, 85-95. http://dx.doi.org/10.1111/j.1944-9720.2004.tb02176.x

Eslami, Z., Al-Buainain, H., \& Tzou, J. (2009). Language Learning Strategies Use by Arabic Speaking Students Learning English through Content Areas. In M Al-Hamly, C Coombe, P Davidson, A Shehada and S Troud (Eds.), Proceedings of the $14^{\text {th }}$ TESOL Arabia Conference (pp. 81-95). UAE, Dubai.

Goh, C. C. M., \& Foong, K. P. (1997). Chinese ESL students' learning strategies: A look at frequency, proficiency, and gender. Hong Kong Journal of Applied Linguistics, 2(1), 39-53.

Green, J., \& Oxford, R. (1995). A closer look at learning strategies, L2 proficiency, and gender. TESOL Quarterly, 29(2), 261-297. http://dx.doi.org/10.2307/3587625

Griffiths, C., \& Parr, J. M. (2001). Language-learning Strategies: Theory and Perception. ELT Journal, 53(1), 247-54.

Gregerson, T. (2000). The Individual Differences that Distinguish High and Low Output Students. Revista Signos, $33,87-99$.

Grenfell, M., \& Harris, V. (1999). Modern languages and learning strategies: In theory and practice. London: Routledge.

Griffiths, C., \& Parr, J. (2001). Language-learning strategies: Theory and perception. ELT Journal, 53(3), 247-254.

Holec, H. (1981). Autonomy and Foreign Language Learning. Oxford, UK: Pergamon Press.

Hon-Nam, K., \& Leavell, A. (2006). Language learning strategy use of ESL students in an intensive English learning context. System, 34, 399-415.

Hsiao, T., \& Oxford, R. (2000). Comparing theories of language learning strategies: a confirmatory factor analysis. The Modern Language Journal, 86(3), 368-383. http://dx.doi.org/10.1111/1540-4781.00155

Javid, C. Z. (2010). Addressing the causes that hinder effective English language teaching in Saudi universities: A case study. Bani-Swaif University Journal, 80, 479-513.

Javid, C. Z. (2011). Saudi medical undergraduates' perceptions of their preferred learning styles and evaluation techniques. Arab World English Journal, 2(2), 40-70. Retrieved from http://www.awej.org

Javid, C. Z., \& Khairi, M. H. (2011). The role of pleasure reading in enhancing reading speed and reading comprehension. Arab World English Journal, 2(4), 219-256. Retrieved from http://www.awej.org

Jurkovič, V. (2010). Effect of Explicit Language Learning Strategy Instruction on Language-test and Self-assessment Scores. English Language Teaching, 3(1), 16-27.

Khalil, A. (2005). Assessment of language learning strategies used by Palestinian EFL learners. Foreign Language Annals, 38(1), 108-119. http://dx.doi.org/10.1111/j.1944-9720.2005.tb02458.x

Lan, R., \& Oxford, R. L. (2003). Language learning strategy profiles of elementary school students in Taiwan. IRAL, 41, 339-379.

Littlejohn, A. (2008). Digging deeper: learners' disposition and strategy use. In G Cane (Ed.), Strategies in language learning and teaching (pp. 68-81). Singapore, RELC. Retrieved from http://www.andrewlittlejohn.net/website/docs/Digging\%20deeper.pdf

Littlewood, W. (1999). Defining and developing autonomy in East Asia contexts. Applied Linguistics, 20(1), 
71-94. http://dx.doi.org/10.1093/applin/20.1.71

Magogwe, J., \& Oliver, R. (2007). The relationship between language learning strategies, proficiency, age and self-efficacy beliefs: A study of language learners in Botswana. System, 35, 338-352.

McDonough, S. H. (1995). Strategy and skill in learning a foreign language. London: Edward Arnold.

Motallebzadeh, K., \& Mamdoohi, N. (2011). Language Learning Strategies: A Key Factor to Improvement of TOEFL Candidates' Reading Comprehension Ability. International Journal of Linguistics, 3(1), 1-11.

Naiman, N., Frohlich, M., Stern, H. H., \& Todesco, A. (1978). The good language learner. Toronto, Ontario, Canada: Ontario Institute for Studies in Education.

Nisbet, D., Tindall, E., \& Arroyo, A. (2005). Language learning strategies and English proficiency of Chinese university students. Foreign Language Annals, 38(1), 100-107.

Nunan, D. (1988). The learner-centered curriculum. Cambridge: University Press.

O'Malley, J. M. (1987). The effects of training in the use of learning strategies on acquiring English as a second language. In A Wenden, \& J Rubin (Eds.), Learning strategies in language learning (pp. 133-144). London: Cambridge University Press.

O'Malley, J. M., \& Chamot, A. U. (1990). Learning strategies in second language acquisition. Cambridge, UK: Cambridge University Press. http://dx.doi.org/10.1017/CBO9781139524490

Oxford, R. (1990). Language learning strategies: What every teacher should know. New York: Newbury House.

Oxford, R. L., \& Cohen, A. D. (1992). Language learning strategies: Crucial issues of concepts and classification. Applied Language Learning, 3(1), 1-35.

Oxford, R., \& Ehrman, M. (1995). Adults' language learning strategies in an intensive foreign language program in the United States. System, 23(3), 359-386.

Oxford, R., \& Nyikos, M. (1989). Variables affecting choice of language learning strategies: A synthesis of studies with implications for strategy training. System, 17, 235-247.

Park, G. (1997). Language learning strategies and English proficiency in Korean university students. Foreign Language Annals, 30(2), 211-221. http://dx.doi.org/10.1111/j.1944-9720.1997.tb02343.x

Peng, I. N. (2001). EFL motivation and strategy use among Taiwanese senior high school learners. Master's thesis, National Taiwan Normal University.

Rababah, G. (2003). Communication Problems Facing Arab Learners of English: A Personal Perspective. TEFL Web Journal, 2(1). Retrieved from http://faculty.ksu.edu.sa/mdajani/Pages/ArabLearners.aspx

Radwan, A. A. (2010). Strategies by university students majoring in English. Asian EFL Journal, 12(1), 115-163.

Raymond, S. M. (2008). Effective and Ineffective University Teaching from the Students' and Faculty's Perspectives: Matched or Mismatched Expectations? Thesis submitted to the University of Exeter in part requirement for the Doctor of Education (EdD). Retrieved from http://eric.exeter.ac.uk/exeter/bitstream/10036/40767/6/RaymondS.pdf

Riazi, A. (2007). Language Learning Strategy: Perceptions of Female Arab English Majors. Foreign Language Annals, 40(3), 433-40.

Rigney, J. W. (1978). Learning Strategies: A theoretical perspective. In H F O'Neil (Ed.), Learning Strategies (pp. 165-205). New York: Academic Press.

Rong, M. (1999). Language learning strategies of a sample of tertiary-level students in the P. R. China. Guidelines, 21(1), 1-11.

Rubin, J. (1975). What the "good language learner" can teach us. TESOL Quarterly, 9, 41-51. http://dx.doi.org/10.2307/3586011

Rubin, J. (1987). Learner strategies: Theoretical assumptions, research history and typology. In A Weden, \& J Rubin (Eds.), Learner strategies in language learning (pp. 15-30). New Jersey: Prentice/Hall Intenational.

Sahu, R. (1999). Improving English Language: Competence of Yemeni Learners. Yementimes, 5.

Salem, N. (2006). The Role of Motivation, Gender and Language Learning Strategies in EFL Proficiency. M.A. Thesis. The American University of Beirut.

Shmais, W. (2003). Language learning strategy use in Palestine. TESL-EJ, 7(2). Retrieved from 
http://tesl-ej.org/ej26/a3.html.

Stern, H. (1975). What can we learn from the good language learner? Canadian Modern Language Review, 31, 304-318.

Tushyeh, H. Y. (1992). The role of EFL teacher training at West Bank universities. An-Najah Journal, 2(6), 7-32.

Wenden, A., \& Rubin, J. (Eds.). (1987). Learner strategies in language learning. London, UK: Prentice Hall.

Wharton, G. (2000). Language learning strategy use of bilingual foreign language learners in Singapore. Language Learning, 50(2), 203-244. http://dx.doi.org/10.1111/0023-8333.00117

Zughoul, M. (1986). English departments in the third world: language, linguistics, or literature? English Teaching Forum, (24), 10-17.

\section{Appendix 1}

\section{Strategy Inventory for Language Learning (SILL)}

\section{Oxford (1990)}

\section{Directions}

This form of the Strategy Inventory for Language Learning (SILL) is for students of English as a second or foreign language.

You will find statements about learning English. Please read each statement. On the separate worksheet, write the response

$(1,2,3,4,5)$ that tells how true of you the statement is.

1. Never or almost never true of me

2. Usually not true of me

3. Somewhat true of me

4. Usually true of me

5. Always or almost always true of me

\section{Part $A$}

1. I think of relationships between what I already know and new things I learn in English.

2. I use new English words in a sentence so I can remember them.

3. I connect the sound of a new English word and an image or picture of the word to help me remember the word.

4. I remember a new English word by making a mental picture of a situation in which the word might be used.

5. I use rhymes to remember new English words.

6. I use flashcards to remember new English words.

7. I physically act out new English words.

8. I review English lessons often.

9. I remember new English words or phrases by remembering their location on the page, on the board, or on a street sign.

\section{Part B}

10. I say or write new English words several times.

11. I try to talk like native English speakers.

12. I practice the sounds of English.

13. I use the English words I know in different ways.

14. I start conversations in English.

15. I watch English language TV shows spoken in English or go to movies spoken in English.

16. I read for pleasure in English.

17. I write notes, messages, letters, or reports in English. 
18. I first skim an English passage (read over the passage quickly) then go back and read carefully.

19. I look for words in my own language that are similar to new words in English.

20. I try to find patterns in English.

21. I find the meaning of an English word by dividing it into parts that I understand.

22. I try not to translate word-for-word.

23. I make summaries of information that I hear or read in English.

\section{Part C}

24. To understand unfamiliar words, I make guesses.

25. When I can't think of a word during a conversation in English, I use gestures.

26. I make up new words if I don't know the right ones in English.

27. I read English without looking up every new word.

28. I try to guess what the other person will say next in English.

29. If I can't think of an English word, I use a word or phrase that means the same thing.

\section{Part D}

30. I try to find as many ways as I can to use my English.

31. I notice my English mistakes and use that information to help me do better.

32. I pay attention when someone is speaking English.

33. I try to find out how to be a better learner of English.

34. I plan my schedule so I will have enough time to study English.

35. I look for people I can talk to in English.

36. I look for opportunities to read as much as possible in English.

37. I have clear goals for improving my English skills.

38. I think about my progress in learning English.

\section{Part $E$}

39. I try to relax whenever I feel afraid of using English.

40. I encourage myself to speak English even when I am afraid of making mistakes.

41. I give myself a reward or treat when I do well in English.

42. I notice if I am tense or nervous when I am studying or using English.

43. I write down my feelings in a language learning diary.

44. I talk to someone else about how I feel when I am learning English.

\section{Part F}

45. If I don't understand something in English, I ask the other person to slow down or say it again.

46. I ask English speakers to correct me when I talk.

47. I practice English with other students.

48. I ask for help from English speakers.

49. I ask questions in English.

50. I try to learn about the culture of English speakers. 